\title{
Protein pattern of canola (Brassica napus L.) changes in response to salt and salicylic acid in vitro
}

\author{
ROYA RAZAVIZADEH \\ Department of Biology, Payame Noor University, PO BOX 19395-3697, Tehran, Iran \\ Corresponding author: Roya Razavizadeh, e-mail: razavi.roya@gmail.com
}

(Received on 30 April 2015; Accepted on 16 December 2015)

\begin{abstract}
The effect of salicylic acid (SA) on the salt $(\mathrm{NaCl})$ tolerance mechanism was studied in canola plants (oilseed rape, Brassica napus L.) by molecular and physiological experiments in plant tissue culture. Seeds of $B$. napus 'Ocapy' were germinated at 0,50 , and $100 \mathrm{mM} \mathrm{NaCl}$ on Murashige and Skoog (MS) medium containing different levels $(0,2$, and $5 \mu \mathrm{M})$ of SA for 4 weeks. Total chlorophyll, carotenoid, and flavonoid content increased in response to interactive effects of $\mathrm{SA}$ and $\mathrm{NaCl}$ treatments at some concentrations. Proline content was increased under salt and SA treatments in shoot and root tissues. Salt alone and in combination with SA increased the total soluble protein content of shoots only, while the different concentrations of SA in the culture media affected variously the total soluble protein content. Protein patterns of shoots and roots showed some remarkable differences, based on gel electrophoresis and the consequent analysis of bands by ImageJ program. The relative expression of 15 and 12 protein bands in shoots and roots, respectively, differed under the applied treatments. In addition, the protein profile indicated that salinity and SA regulate the expression of salt-stress-inducible proteins as well as induced de novo synthesis of specific polypeptides. The findings may help to explain the salt tolerance mechanisms and to produce salt-tolerant canola plants.
\end{abstract}

Keywords: oilseed rape, Brassica napus, canola, protein, proline, salinity, salicylic acid.

\section{INTRODUCTION}

Salinity is a considerable agronomic problem in one third of the world's irrigated lands and half of the lands in semiarid and coastal regions (EPSTEIN et al. 1980). Excessive salinity adversely affects all major physiologic and metabolic activities of plants (Gepstein et al. 2006; Blumwald \& Grover 2006; SAHiahi et al. 2006; JAmiL et al. 2012). Higher plants respond to the salt stress by using molecular and cellular regulation of their processes at various levels. Transcriptional and translational pathways are important determinants in regulating salt stress responses (SAHI et al. 2006). Therefore, physiological measurements combined with the evaluation of proteins, 
e.g. global expression profiling (KANG et al. 2012), can be useful tools to explain the salt tolerance mechanisms in plants.

The development of approaches to induce salt stress tolerance in crop plants is vital and still receives considerable attention. In the past 2 decades, many biotechnological researches have provided considerable insights into the mechanism of environmental stress tolerance in plants at the molecular level (HAMIDIA \& SHADDAD 2010). Treatment with growth regulators (SENARATNA et al. 2000; BANINASAB \& GHOBADI 2011), such as salicylic acid (SA), as well as genetic engineering (MCKERISE et al. 1988), traditional breeding (VETTAKKORUMAKANKAV et al. 1999) and in vitro selection, are methods used to develop salt-tolerant plants so far. According to some investigators, SA should be categorized as a phytohormone (RASKIN 1992), which participates in the regulation of growth and development of plants. In plants, SA can regulate some of the key physiological functions, such as ion uptake and transport (GLASS 1975; KAYDAn et al. 2007), stomatal function (LARQUE-SAAYEDRA 1979; RASKIN 1992), disease resistance (RASKIN 1992; KLESSIG \& MALAMY 1994), and so on. Furthermore, the capability of SA to moderate adverse effects of salinity in crop plants has been reviewed by GHORBANI JAVID et al. (2011). However, information about the influence of this phenolic compound on the plant functions and metabolism is still limited (MohareKar et al. 2003) and more attention needs to be paid to SA effects on higher plants.

Oilseed rape (Brassica napus L.), also known as canola (cultivars with a low erucic acid content), is one of the major crops in the Mediterranean and some regions of the Middle East (ByBordi 2010). Brassica species are ancient crop plants, belonging to the family Brassicaceae (Cruciferae, also known as the mustard family), are used as oilseed crops (B. napus and B. juncea), leafy and root vegetables (B. oleracea and $B$. rapa), and are cultivated worldwide (SADIA et al. 2009). The nutritive value of oilseed rape, as the third largest oilseed crop in the world, is related to a high amount of oleic acid and a low amount of saturated fatty acids (NASR et al. 2006). $B$. napus provides approximately $13 \%$ of the world's supply of vegetable oil (HAJDUCH et al. 2006). Furthermore, seeds of canola are rich in proteins. B. napus produces seeds with approximately $40 \%$ oil and $15 \%$ protein as the main storage compounds (NoRTON \& HARRIs 1975; Gunstone et al. 1995). The nutritive and economic value of canola caused the rise in the cultivation of Brassica species even on salt-affected soils in arid and semi-arid regions. Therefore, increasing its salt tolerance using different approaches has enormous advantages.

The main objective of this study was to evaluate whether the exogenously applied SA could alleviate the adverse influences of salinity in canola plants under in vitro conditions. Plant tissue culture techniques allow close monitoring and precise manipulation of plant growth and development. Moreover, the in vitro system offers the advantage that relatively little space is needed to culture plants and this system allows a rigorous control of the physical environment and nutrient status parameters, which are difficult to regulate with traditional experimental systems. Furthermore, any complex organ-organ and plant-environment interaction can be controlled or removed, and the level of stress can be accurately and conveniently controlled. The salt stress responses of $B$. napus were assessed at the gene product level by one dimen- 
sional gel electrophoresis, in relation to other key physiological parameters, such as photosynthetic capacity, carotenoids, flavonoids, and proline content of canola shoots and roots under SA treatment.

\section{MATERIAL AND METHODS}

Brassica napus 'Ocapy' was used to compare concentrations of photosynthetic pigments, flavonoids, proline, total soluble protein content, and protein pattern (by using sodium dodecyl sulfate polyacrylamide gel electrophoresis, SDS-PAGE) under salt and SA treatments. The seeds were provided by the Oil Seed Cultivation Company, Isfahan, Iran. Mature seeds (70 days after pollination) were grown on MS (Murashige \& Skoog 1962) medium containing 0 (control), 50 or $100 \mathrm{mM} \mathrm{NaCl}$ and 0,2 or $5 \mu \mathrm{M}$ SA. All cultures were kept in the culture room with a $16 / 8 \mathrm{~h} \mathrm{light/dark}$ photoperiod at $25 \pm 2^{\circ} \mathrm{C}$ for 4 weeks.

Photosynthetic pigments (total chlorophyll and carotenoids) were extracted according to LichtenTHALER's (1987) method: $0.05 \mathrm{~g}$ of leaves from 4-week-old canola plants were homogenized using $80 \%$ acetone in darkness. Their concentrations were measured at 663.2, 646.8 and $470 \mathrm{~nm}$ by a spectrophotometer and expressed as $\mathrm{mg} / \mathrm{g}$ FW.

The total flavonoid content of samples was measured as described by KRIZEK et al. (1998): $0.05 \mathrm{~g}$ of leaves were homogenized in $2.5 \mathrm{ml}$ acidified ethanol (ethanol: glacial acetic acid, 99:1, v/v), and then the extract was centrifuged at $4000 \mathrm{~g}$ for $5 \mathrm{~min}$ at room temperature. The supernatant was kept at $85^{\circ} \mathrm{C}$ for $10 \mathrm{~min}$ in the water bath. Absorbance was recorded at 270, 300, and $330 \mathrm{~nm}$, and flavonoid content was expressed as $\mathrm{mg} / \mathrm{g}$ FW.

Free proline content of frozen samples (shoot and root) at $-20^{\circ} \mathrm{C}$ was measured as described by CARILLO \& GIBON (2011), using the cold extraction procedure. Plant samples $(0.1 \mathrm{~g}$ of shoot or $0.03 \mathrm{~g}$ of root) were homogenized and diluted 20 to 50 times $(\mathrm{w} / \mathrm{v})$ with ethanol:water $(70: 30, \mathrm{v} / \mathrm{v})$. The resulting mixtures were left overnight a $4^{\circ} \mathrm{C}$, and then centrifuged at $14000 \mathrm{~g}$ for 5 min at $4^{\circ} \mathrm{C}$ (CARILlo et al. 2008; Hummel et al. 2009). Next, $1000 \mu \mathrm{l}$ of the reaction mixture, including ninhydrin $(1 \%$, $\mathrm{w} / \mathrm{v})$ in acetic acid $(60 \%, \mathrm{v} / \mathrm{v})$, and ethanol $(20 \%, \mathrm{v} / \mathrm{v})$, was mixed with $500 \mu \mathrm{l}$ of plant ethanolic extract and the tubes were sealed, mixed and heated at $95^{\circ} \mathrm{C}$ in the block heater for $20 \mathrm{~min}$. For standard samples of proline, $1000 \mu \mathrm{l}$ of the reaction mix was mixed with $100 \mu$ of $0.2,0.5,1,2,5 \mathrm{mM}$ proline standard completed with up to $400 \mu \mathrm{l}$ of ethanol:water $(40: 60, \mathrm{v} / \mathrm{v})$ and the tubes were sealed, mixed, and heated at $95^{\circ} \mathrm{C}$ in the block heater for $20 \mathrm{~min}$. The mixtures were then centrifuged at 10000 rpm for $1 \mathrm{~min}$ and the supernatants were transferred to a $1.5 \mathrm{ml}$ cuvette. The absorbance of each supernatant was read at $520 \mathrm{~nm}$. Proline concentration was determined using a calibration curve and expressed as $\mu \mathrm{mol} / \mathrm{g}$ FW.

Approximately $0.1 \mathrm{~g}$ of fresh shoot and $0.03 \mathrm{~g}$ of root from the 4-week-old plants were used in the protein assay. Protein extraction was carried out according to RosTAMI \& EHSANPOUR's (2009) modified method using an extraction buffer (50 mM Tris-HCl, $1 \mathrm{mM}$ dithiothreitol, $2 \mathrm{mM}$ EDTA, $2 \mathrm{mM}$ 2-mercaptoethanol, $\mathrm{pH}$ 7.5). Total soluble protein $\left(\mathrm{mg} \mathrm{g}^{1-} \mathrm{FW}\right)$ in protein extracts from stem-leaf and root tissues was determined 
according to BRADFORD's modified method (1976), as described by OLSON \& MARKWELL (2007), using bovine serum albumin as the standard protein. SDS-PAGE was performed using $12.5 \%$ separating and 5\% stacking gels. The gel electrophoresis was carried out with an equivalent amount: 10 and $20 \mu \mathrm{g}$ protein for shoot and root samples, respectively. After electrophoresis at $130 \mathrm{~V}$, protein bands were stained using silver nitrate according to SALEHI \& MCCARTHY's method (2002), and finally protein bands showed remarkable changes, which were analysed by ImageJ software.

In order to be more accurate, experiments were repeated at least 3 times and the mean values \pm the standard deviation were presented. The obtained data were subjected to analysis of variance (ANOVA), using the statistical package Sigmastat 2.01, and the mean differences were compared by the Duncan test at $p<0.05$.

\section{RESULTS AND DISCUSSION}

The present study was conducted to evaluate the exogenous application of SA on canola seeds growing upon a medium containing $\mathrm{NaCl}$ in the plant tissue culture system. Overall, the results demonstrated that SA could alleviate salt stress effects on physiological parameters of canola plants under in vitro conditions.

The total chlorophyll content was significantly reduced under all salt concentrations and SA treatments, in comparison to the control, but the interactive effects of SA levels and salt increased it markedly, especially at $100 \mathrm{mM} \mathrm{NaCl}$. The highest total chlorophyll content was recorded at the higher salinity level, with $5 \mu \mathrm{M} \mathrm{SA}$ (Fig. 1A). Salt alone increased carotenoid content especially at $50 \mathrm{mM}$. SA alone, at $2 \mu \mathrm{M}$, caused a significant reduction of carotenoid content, in comparison to the control plants. However, 2 and $5 \mu \mathrm{M}$ of SA significantly increased the level of carotenoids in presence of salt stress (Fig. 1B).

Photosynthetic pigments (total chlorophyll and carotenoids) of B. napus seedlings were significantly affected by salinity, SA, and their interactions. Chlorophyll has a unique and essential role in higher plants (ECKHARDT et al. 2004). Biosynthesis and breakdown of chlorophyll in higher plants are complex pathways that are regulated by different factors. However, photosynthesis, as a key metabolic pathway in higher plants, as well as photosynthetic pigments, are targets for salt stress (BORSANI et al. 2001). LEUNG et al. (1994) demonstrated that production of abscisic acid (ABA) in response to salt stress decreases turgor in guard cells and limits the $\mathrm{CO}_{2}$ available for photosynthesis. The synthesis of ABA closes stomata, and stomatal closure results in photosynthesis decline, photoinhibition, and oxidative stress (ZHU 2007). It is also suggested that ROS production can be responsible for the deleterious effects of salt stress on chlorophyll content and chloroplast ultrastructure (YAMANE et al. 2004). The reduction of total chlorophyll of canola plants in the present study may be attributed to the toxic action of $\mathrm{NaCl}$ on the biosynthesis of pigments or increasing degradation of the photosynthetic apparatus (BARAKAT 2011). Similar findings have also been reported by EL-ShinABy et al. (2002), MittoyA et al. (2004), and YAMANE et al. (2004) in cultivated maize, tomato, and rice grown under salinity stress, respectively. In addition, PANCHeva et al. (1996) and MoHAREKAR et al. (2003) reported the reduction of chlorophyll content by applying SA, and concluded that these results 

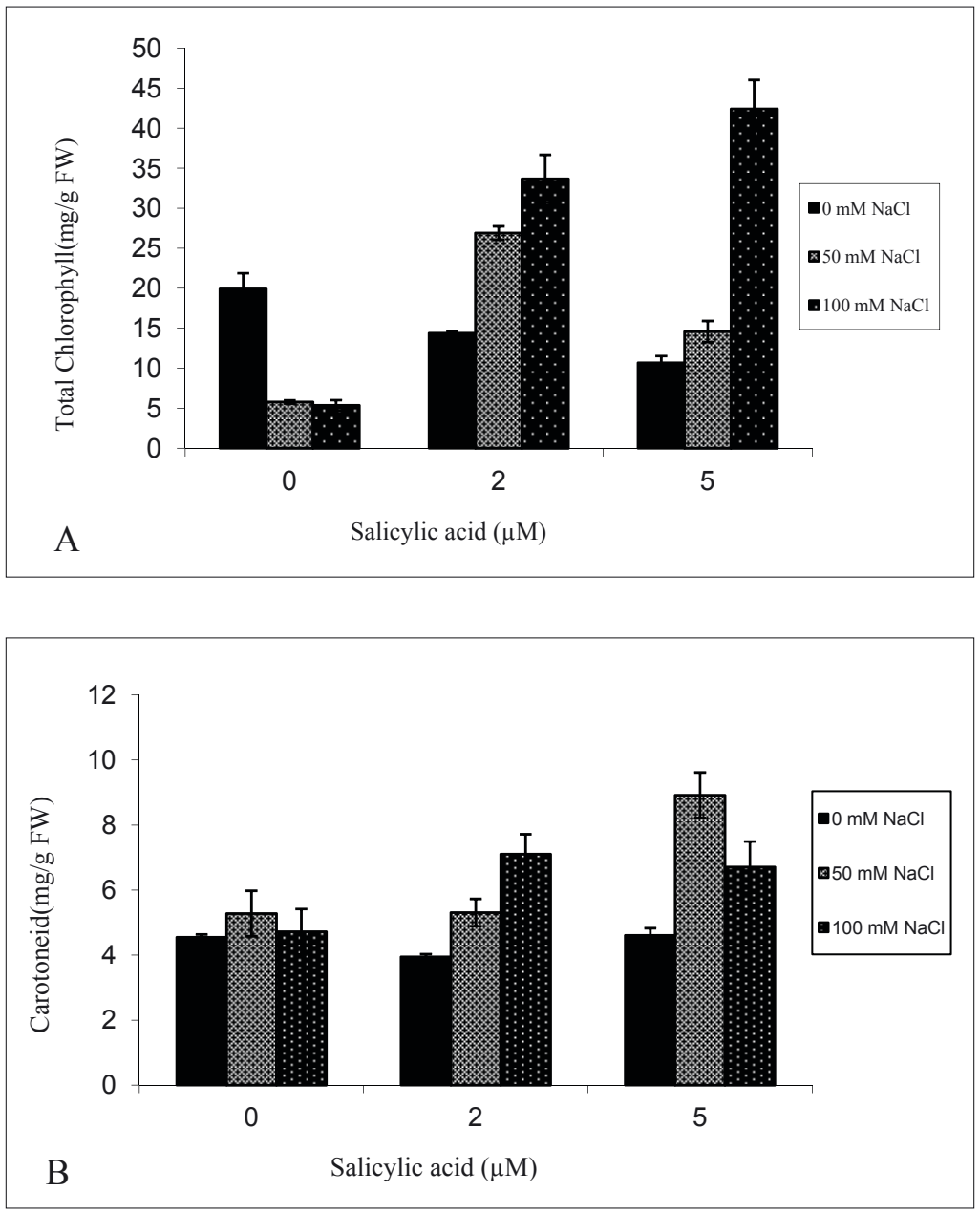

Fig. 1. Total chlorophyll (A) and carotenoid content (B) of Brassica napus leaves under salt and salicylic acid (SA) treatments. Values are means of 3 replications \pm standard deviation

might be of some plant protective value. The increasing chlorophyll content under interactions of salt and SA may be strongly related to the inhibiting effect of SA on $\mathrm{Cl}^{-}$and $\mathrm{Na}^{+}$toxicity and protection against oxidative stress induced by salinity. Similar results have also been reported for maize (Zea mays L.) by Leven TunA et al. (2007), for basil (Ocimum basilicum L.) by Delavari et al. (2010), for 2 mung bean cultivars (Vigna radiata (L.) R. Wilczek) by NAZAR et al. (2010), for wheat (Triticum aestivum L.) by KANG et al. (2012), and for tomato (Lycopersicon sativus ) by WASTI et al. (2012). Carotenoids, as natural antioxidants in higher plants, protect 
the photosynthetic apparatus under biotic and abiotic stresses (SIEFERMANN-HARMS 1987; Panda \& Biswal 1989; Srichandan et al. 1989; Demmig-Adams 1990; Young 1991). In the present study, carotenoids positively correlated with salinity at some concentrations and negatively with SA, whereas positive correlations were observed between the interactive effects of salinity and SA with carotenoid content of leaves. In closely related studies, TARI et al. (2002) and BARAKAT (2011) found similar results on tomato and wheat plants, respectively. On the other hand, HASHEMI et al. (2010) determined that carotenoids decreased after application of SA in deadly nightshade (Atropa belladonna L.). The high accumulation of chlorophyll and carotenoids as a result of the exogenous application of $\mathrm{SA}$ in presence of $\mathrm{NaCl}$ may be due to the increase in photosynthetic efficiency under the salt stress conditions in canola plants.

As shown in Fig. 2 (A, B and C), salinity caused a significant reduction in flavonoid content at 270, 300 and $330 \mathrm{~nm}$, while SA treatments alone did not show any significant effects on flavonoid content in comparison to the control. A significant increase was observed in flavonoids after application of $100 \mathrm{mM} \mathrm{NaCl}$ and SA treatments at the 3 wavelengths. My experiments show that salinity independently led to a decrease in flavonoids, while in combination with SA it caused an increase in their accumulation. The flavonoid content was not influenced by SA treatments alone. The flavonoids, as the largest group of secondary products in plants (HASLAM 1998; VERVERIDIs et al. 2007), have vast biological functions, including evident roles in stress protection (KLIEBENSTEIN 2004). The reduction of these phenolic compounds in the present study may be related to the toxic levels of salt stress on the production of the pigments. Moreover, there is also evidence that flavonoids function as phytochemical antioxidants in maintaining the stable concentration of free radicals by removing them from stress conditions (Christoffersen \& LATIES 1982; Schaller $\&$ KIEBER 2002). The positive correlation between the application of SA in presence $\mathrm{NaCl}$ and total flavonoids in this study shows that the increase in SA levels possibly induces the production of flavonoids and activation of the antioxidant system in canola plants in response to salinity. Furthermore, previous studies revealed that SA caused an increase in plant resistance, with an effect on ethylene biosynthesis. Ethylene, as a phytohormone, can enhance the production of enzymes that are involved in biosynthesis of phenolic compounds, such as phenylalanine ammonialyase (HYODA \& YANG 1971; SAKAKI et al. 1983). Therefore flavonoid formation in this study could be related to the effects of high endogenous ethylene on the flavonoids in response to the interactive SA and salt stress. The results of my study demonstrated that the treatment of canola plants with salt and SA increased significantly the production or accumulation of all the pigments.

The enhancement of proline production was recorded not only under salt and SA treatments but also in response to $\mathrm{NaCl}$ and $\mathrm{SA}$ interactions, especially in shoot tissues. The highest amount of proline was observed at $50 \mathrm{mM} \mathrm{NaCl}$ and $5 \mu \mathrm{M} \mathrm{SA}$ in shoots, while it was higher at $100 \mathrm{mM} \mathrm{NaCl}$ and $2 \mu \mathrm{M}$ SA in roots. The effects of salt stress alone induced a marked increase in the proline level in roots, especially at 100 $\mathrm{mM} \mathrm{NaCl}$, while under SA treatment the proline content of roots did not show any significant increase (Fig. 3A-B). Higher plants change their proline concentration, as an osmolyte, in response to a wide range of environmental stresses (PAVLiHOVA et al. 

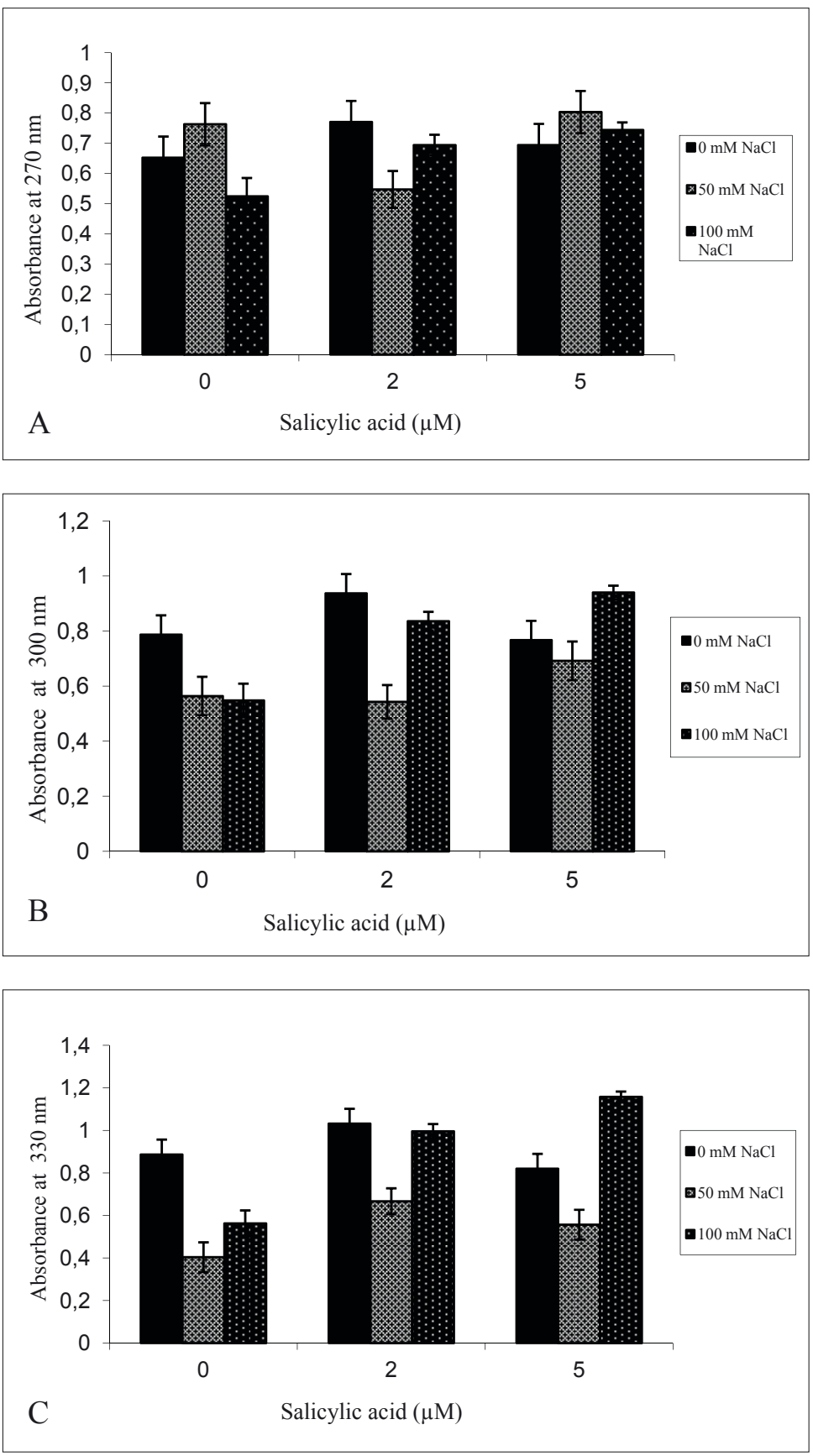

Fig. 2. Flavonoid content of Brassica napus leaves at $270 \mathrm{~nm}$ (A), $300 \mathrm{~nm}$ (B), and $330 \mathrm{~nm}$ (C) under salt and salicylic acid (SA) treatments. Values are means of 3 replications \pm standard deviation 

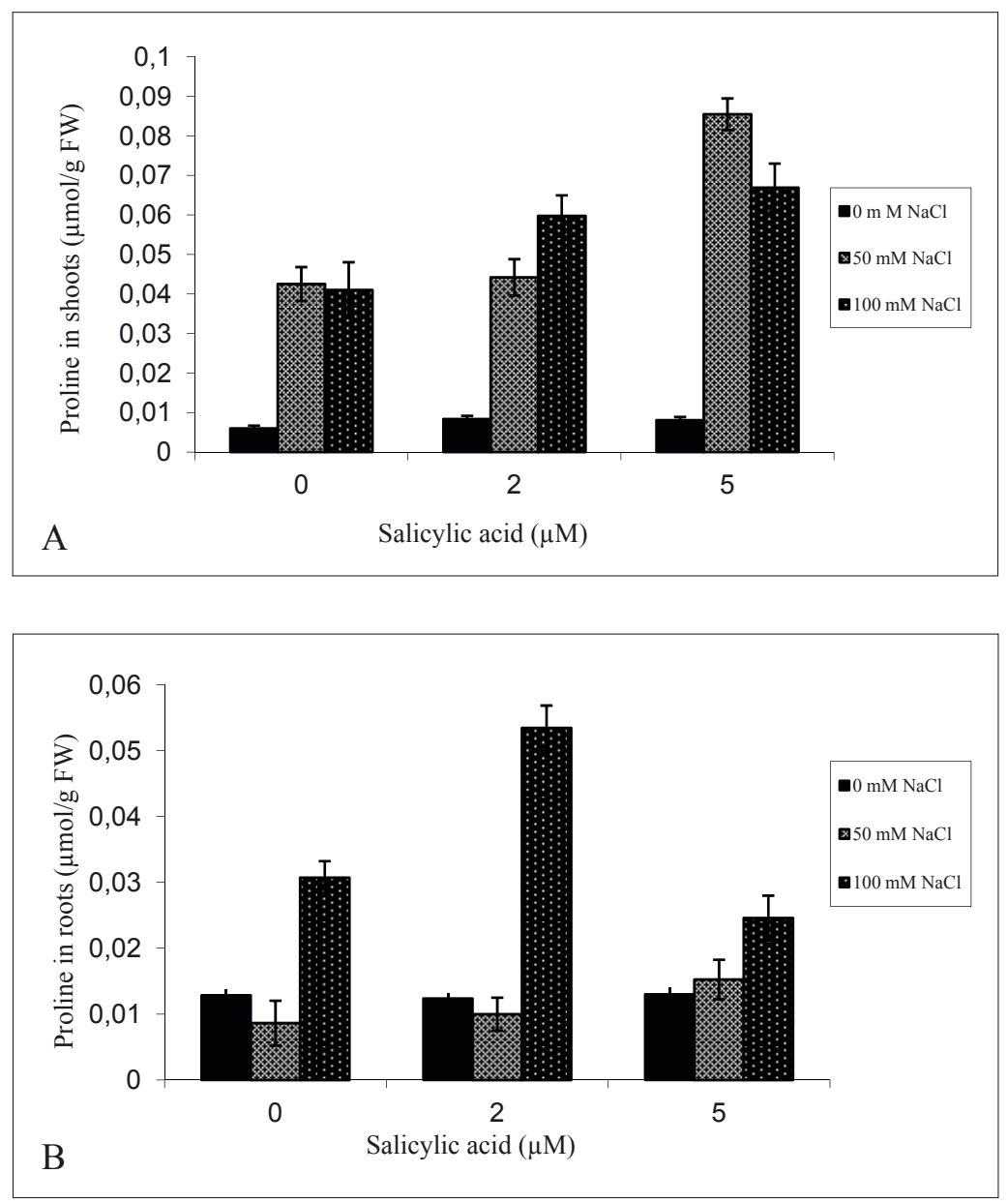

Fig. 3. Proline content of Brassica napus shoots (A) and roots (B) under salt and salicylic acid (SA) treatments. Values are means of 3 replications \pm standard deviation

2008). The determination of this amino acid is therefore very useful in assessing the physiological status and more generally in understanding the stress tolerance and resistance in plants (CARILLO \& GIBON 2011). During different stresses, proline behaves as an adaptive factor, compatible osmolyte, carbon and nitrogen storage compound, $\mathrm{pH}$ stabilizer, cell redox balancer, and stress-related growth-regulator (HARE \& CRESS 1997; Maggio et al. 2002; Khedr et al. 2003; Trovato et al. 2008; Verbruggen \& Hermans 2008; Mattioli et al. 2009; Szabados \& Savour 2010). Vasakova \& Stefl (1982) demonstrated that the activity of a key enzyme, glutamate kinase, in the biosynthetic pathway of proline is affected by the production and accumulation rate of 

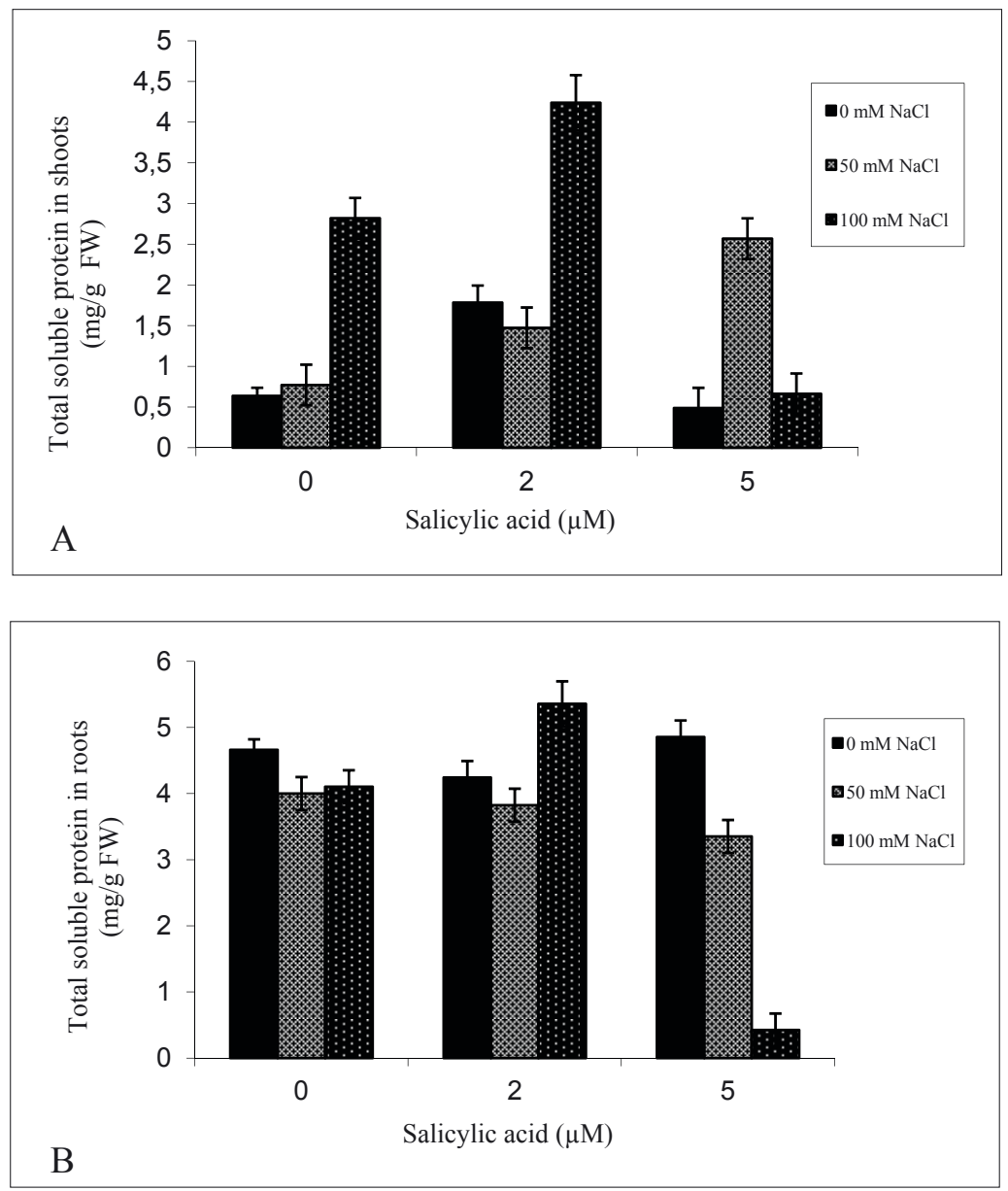

Fig. 4. Total soluble proteins in Brassica napus shoots (A) and roots (B) under salt and salicylic acid (SA) treatments. Values are means of 3 replications \pm standard deviation

this osmoprotectant. Under experimental conditions the treatment of canola plants with salt and SA caused an increase in proline concentration. In agreement with the present results, previous studies have indicated an increase in proline and other amino acids under SA and salt stress (Hussein et al. 2007; Misra \& SAXENA 2009). Similarly, proline enhancement has been shown in Pancratium maritimum L. (KHEDR et al. 2003). Results of this study indicate that proline production rate was more sensitive to salinity than to SA. Thus the increased accumulation of proline may be a general response to salinity stress and accumulated proline may provide efficient energy to increase salinity tolerance with or without SA (GIRIJA et al. 2002). 
The application of different concentrations of salt and SA had various effects on the total soluble protein content. It increased significantly with increasing levels in shoots, while different concentrations of $\mathrm{NaCl}$ decreased the total soluble protein in root tissues, as compared to the control plants. SA-treated plants exhibited a high accumulation of total soluble protein in shoots, especially at $2 \mu \mathrm{M}$ SA. However, the total protein content of roots was not affected by SA treatment. On the other hand, the protein content was changed variously at different concentrations of SA in presence of $\mathrm{NaCl}$. The protein content of shoots was also increased by the interaction of 50 $\mathrm{mM} \mathrm{NaCl}$ and all SA treatments, whereas the protein content of roots was decreased by the interaction of $100 \mathrm{mM} \mathrm{NaCl}$ and $5 \mu \mathrm{M}$ of SA. The highest value of total soluble protein was recorded at the higher salinity level with $2 \mu \mathrm{M} \mathrm{SA}$ in shoots and roots, as compared to the control plants (Fig. 4A-B).

The protein pattern of shoots and roots in one-dimensional polyacrylamide gel electrophoresis (SDS-PAGE) and analysis of bands by ImageJ program showed some remarkable differences. The relative expression of 15 protein bands in shoots and 12 protein bands in roots of Brassica changed under salt and SA treatments in comparison to the control (Figs. 5 and 6A-B). The shoot protein pattern and relative intensity of protein expression show that the expression of protein bands $4,5,6,9$, and 14 (with molecular weights of about 57, 45, 42, 34 and $13 \mathrm{kDa}$, respectively) was up-regulated by salinity, while the expression of protein bands 7 and 11 (with molecular weights of about 40 and $16 \mathrm{kDa}$, respectively) was down-regulated under salt stress. SA levels decreased significantly the relative intensity of protein expression in protein bands 3 $(60 \mathrm{kDa}), 4,5,7$, and 9 . The relative intensity of protein expression in protein bands 11 and 14 was up-regulated, while protein bands 3, 4, and 8 (approximate molecular weight $35 \mathrm{kDa}$ ) were down-regulated by $\mathrm{SA}$ and $\mathrm{NaCl}$ interactions. The appearance of novel protein bands (including 10, 12, and 13, wih molecular weights 26, 15, and $14 \mathrm{kDa}$, respectively) was induced by $100 \mathrm{mM} \mathrm{NaCl}$ and $2 \mu \mathrm{M}$ SA interaction, whereas band 1 (with molecular weight $95 \mathrm{kDa}$ ) was detected at $100 \mathrm{mM} \mathrm{NaCl}$ with 0,2 , and $5 \mu \mathrm{M} \mathrm{SA}$. On the other hand, protein bands 6 and 11 were not present in 0 $\mathrm{mM} \mathrm{NaCl}$ and $2 \mu \mathrm{M} \mathrm{SA}$ interaction. The highest expression of protein bands 2 (72 $\mathrm{kDa}), 3$, and 7 was found in the control, while protein bands 4 and $15(11 \mathrm{kDa})$ were found at $50 \mathrm{mM} \mathrm{NaCl}$ and the combination of $100 \mathrm{mM} \mathrm{NaCl}$ with $2 \mu \mathrm{M} \mathrm{SA}$, respectively. Based on the results of the protein pattern and the relative intensity of protein expression of roots, protein bands 5, 6, 9, 11, and 12 (approximate molecular weight of $47,41,34,15$, and $11 \mathrm{kDa}$ ) were up-regulated by salinity and SA treatments alone and in combination. Moreover, the up-regulation of protein bands 1 and 2 (approximate molecular weights 57 and $55 \mathrm{kDa}$ ) was detected after SA treatments. Overall, the results demonstrated that $\mathrm{NaCl}$ and $\mathrm{SA}$ treatments and their combinations did not decrease the relative expression of proteins in roots. The expression of protein bands 11 and 12 was not detected in the control plants. On the other hand, the induction of protein bands 4 and 10 (48 and $16 \mathrm{kDa}$ ) was found at $100 \mathrm{mM} \mathrm{NaCl}$ and $5 \mu \mathrm{M} \mathrm{SA}$. Furthermore, in response to the interaction of SA levels and $100 \mathrm{mM} \mathrm{NaCl}$, canola plants induced the appearance of protein band $7(40 \mathrm{kDa})$, whereas protein band 8 $(35 \mathrm{kDa})$ was found in $\mathrm{SA}$ treatments alone. The highest expression of protein bands 1 and 2 was found at $5 \mu \mathrm{M}$ SA alone, while it was also detected in response to the 
A
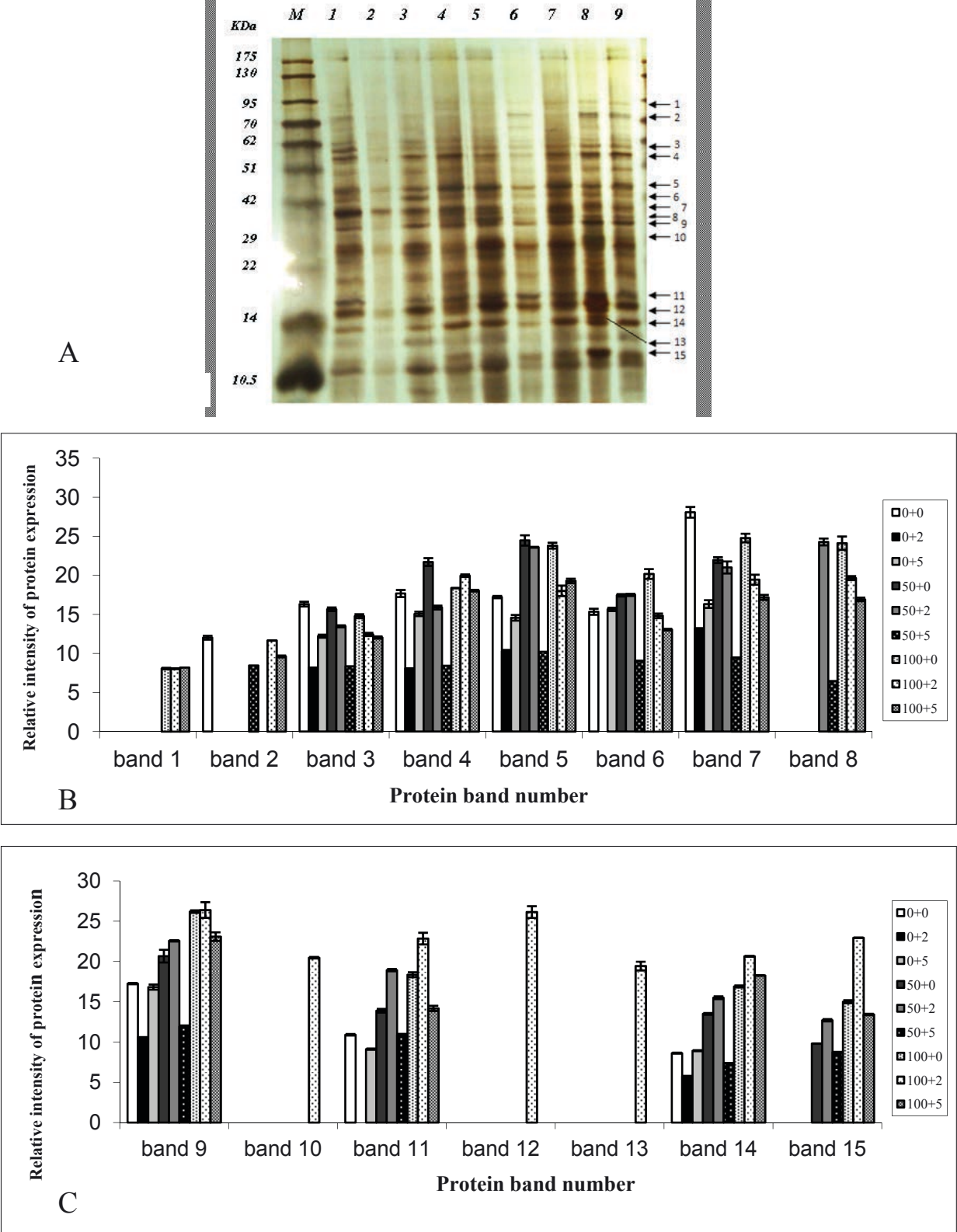

Fig. 5. (A) SDS-PAGE pattern of total soluble proteins in shoots of Brassica napus under salt and salicylic acid (SA) treatments. $\mathrm{M}=$ protein marker; $1=0 \mathrm{mM} \mathrm{NaCl}+0 \mu \mathrm{M} \mathrm{SA} ; 2=0 \mathrm{mM} \mathrm{NaCl}+2$ $\mu \mathrm{M} \mathrm{SA} ; 3=0 \mathrm{mM} \mathrm{NaCl}+5 \mu \mathrm{M} \mathrm{SA} ; 4=50 \mathrm{mM} \mathrm{NaCl}+0 \mu \mathrm{M} \mathrm{SA} ; 5=50 \mathrm{mM} \mathrm{NaCl}+2 \mu \mathrm{M} \mathrm{SA}$; $6=50 \mathrm{mM} \mathrm{NaCl}+5 \mu \mathrm{M} \mathrm{SA} ; 7=100 \mathrm{mM} \mathrm{NaCl}+0 \mu \mathrm{M} \mathrm{SA} ; 8=100 \mathrm{mM} \mathrm{NaCl}+2 \mu \mathrm{M} \mathrm{SA} ; 9=$ $100 \mathrm{mM} \mathrm{NaCl}+5 \mu \mathrm{M}$ SA. (B) Relative levels of protein expression in Brassica napus shoots under salt and salicylic acid (SA) treatments. Values are means \pm standard deviation of proteins bands 

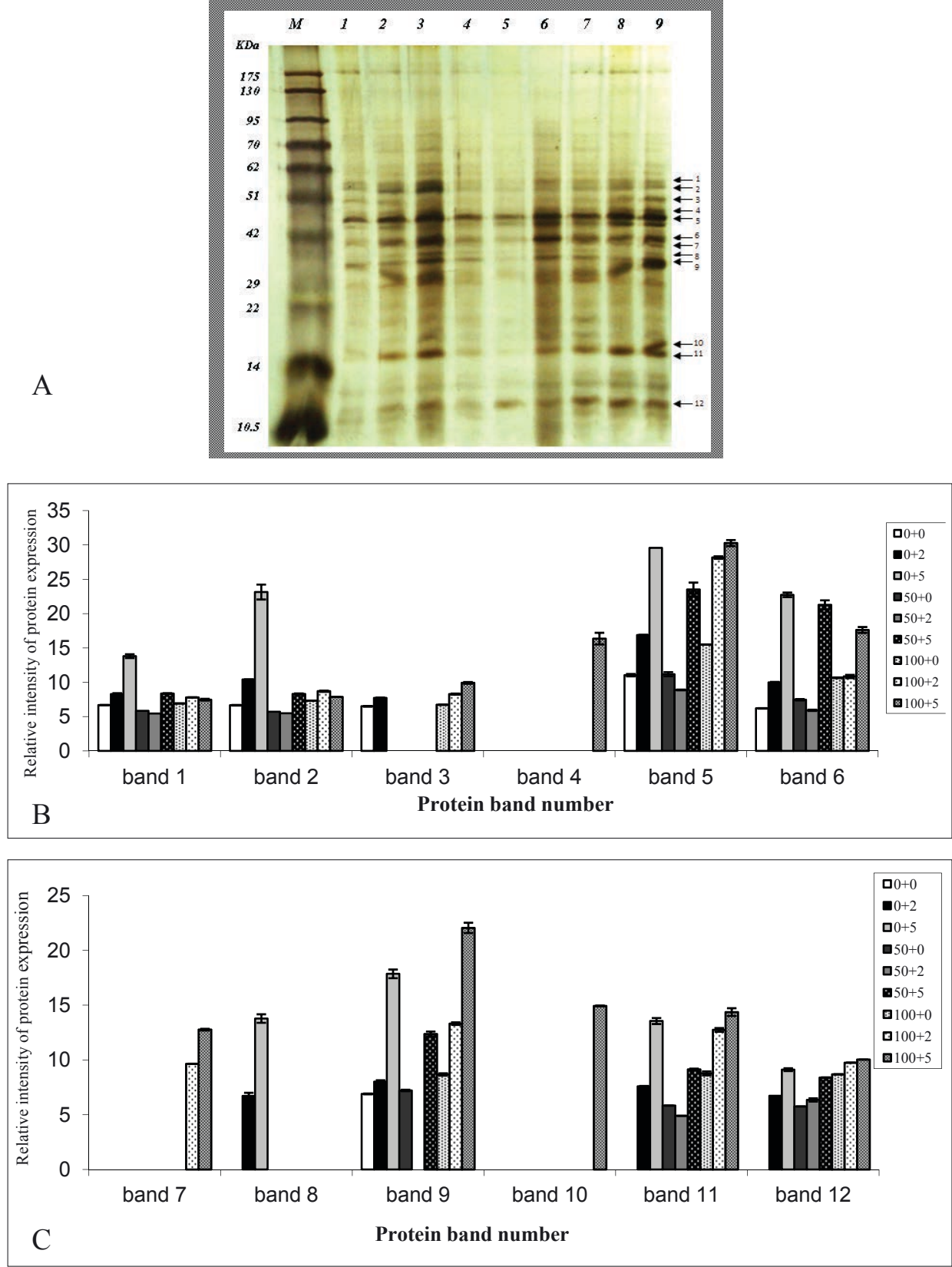

Fig. 6. (A) SDS-PAGE pattern of total soluble protein from Brassica napus roots under salt and salicylic acid (SA) treatments. $\mathrm{M}=$ protein marker; $1=0 \mathrm{mM} \mathrm{NaCl}+0 \mu \mathrm{M} \mathrm{SA} ; 2=0 \mathrm{mM} \mathrm{NaCl}+2$ $\mu \mathrm{M} \mathrm{SA} ; 3=0 \mathrm{mM} \mathrm{NaCl}+5 \mu \mathrm{M} \mathrm{SA} ; 4=50 \mathrm{mM} \mathrm{NaCl}+0 \mu \mathrm{M} \mathrm{SA} ; 5=50 \mathrm{mM} \mathrm{NaCl}+2 \mu \mathrm{M} \mathrm{SA} ;$ $6=50 \mathrm{mM} \mathrm{NaCl}+5 \mu \mathrm{M} \mathrm{SA} ; 7=100 \mathrm{mM} \mathrm{NaCl}+0 \mu \mathrm{M} \mathrm{SA} ; 8=100 \mathrm{mM} \mathrm{NaCl}+2 \mu \mathrm{M} \mathrm{SA} ; 9=$ $100 \mathrm{mM} \mathrm{NaCl}+5 \mu \mathrm{M}$ SA. (B) Relative levels of protein expression in roots of Brassica napus under salt and salicylic acid (SA) treatments. Values are means \pm standard deviation of proteins bands 
combination of $100 \mathrm{mM} \mathrm{NaCl}$ with $5 \mu \mathrm{M} \mathrm{SA}$ and in the higher SA level for protein band 5 .

Within plant cells, proteins are final products of genetic pathways, which are produced in response to cellular needs and transferred to proper locations during different stages of life and stress conditions. According to the presented results, salt alone and in combination with SA levels significantly increased the total protein content of shoots only, while the total protein content of roots was decreased by salinity or SA alone and their interactions. Furthermore, at the highest SA concentration, protein content of shoots and roots was similar or lower than in the control, while it was increased in shoots at low SA concentrations. Several studies, however, indicated that protein level decreased because of salinity effects but SA could increase it (SHAHBA et al. 2010). A decrease in leaf protein content was also reported by JAMIL et al. (2012) under salt stress in sugar beet (Beta vulgaris L.). This finding indicated that changes in protein content may be dependent on plant species and different concentrations of applied salt and SA treatments. In general, the perception and activation of stress signal transduction pathways requires expression of specific sets of genes and finally targets proteins, which are involved in cellular protection or transcription factors controlling specific sets of stress-regulated genes (XIONG et al. 2002). Therefore, the observed enhancements of total protein content may be related to the production of plant proteins involved in perception of salt stress and SA treatment. Products of these genes may be stress-responsive proteins or participate in the generation of regulatory molecules, like ABA and ethylene (XIONG et al. 2002), which are indirectly involved in stress tolerance processes. On the other hand, the results demonstrate that proline was increased under salt and SA treatments in shoot and root tissues. As mentioned above, the rapid accumulation of proline is a typical response to various biotic and abiotic stresses (PAVLiKova et al. 2008). Therefore, plants may use the increased proline content for biosynthesis of physiologically specific proteins, namely stress proteins, such as proline-rich proteins (STEFL \& VASAKova 1984). Despite the increase in root proline content, the observed reduction of protein may be due to the transfer of proline from roots to shoots. Moreover, the cause of protein reduction under salinity conditions in roots may be the prevention of nitrate reductase activity (UNDOVENKo 1971) or the protein synthesis reduction (KONG-NGERN et al. 2005). These results also corroborate the results of research on wheat seedlings (HAmID et al. 2010; Barakat 2011), alfalfa (Medicago sativa L.) (Antoline \& SAuchez-Dais 1992), and barley (Hordeum vulgare L.) (EL-TAYEB 2005).

The change in phytohormone balance plays an important role in regulating plant responses to environmental stresses. Consequently, plants can change the relative intensity of protein expression, osmoprotectants, and osmolytes under stress. Thus the plant proteome analysis can be a useful tool for the evaluation of plant genome changes in response to different stresses. Like in some earlier studies, the presented results show that the appearance and expression of the specific protein bands was affected by salinity, SA treatment alone, and their interactions (LoPES et al. 1994; LiU \& Zhu 1997; PARIDA et al. 2005). The observed alterations in the protein synthesis pattern by salinity and/or SA might predict the presence of several osmoresponsive genes for production of osmoprotective compounds, which are known as compatible 
solutes (Hussain et al. 2008) and may be involved in salt tolerance of canola and osmotic adjustments (LIU \& ZHU 1997; PARIDA et al. 2005; VIJAYAN 2009). In the present study, the induction of the $26-\mathrm{kDa}$ protein and the up-regulation of the $16-\mathrm{kDa}$ protein were observed in shoots in relation to interactions of salinity and SA levels. These proteins may be involved in the synthesis of osmoprotective compounds and/ or may be related to pathogenesis-related proteins (PR-proteins) in plant defence. Similar changes were reported for the induction of a $26-\mathrm{kD}$ a protein by SAMIA et al. (2009) and for the induction a 16-kDa protein by PRZYMUSIŃSKI et al. (2005). Also, the induction of the $35-\mathrm{kDa}$ protein (by SA treatments) and the $48-\mathrm{kDa}$ protein (by the interactions of salinity and SA levels) was shown in roots. The induction of the 48-kDa protein may be speculated to represent SIPK (SA-induced protein kinase) under osmotic stress in plants (ZhANG \& KLESSig 1997; BurKhanOva et al. 1999; MikoŁAJCZYK et al. 2000). On the other hand, based on the available literature, SA can induce abiotic stress tolerance in plants by regulating the expression of certain receptor protein kinases. Similar results were obtained by BorSANI et al. (2001) and SAmia et al. (2009).

All in all, results of this study indicate that the SA-induced alternations in protein expression and/or de novo synthesis of specific proteins may enhance the salt tolerance of canola under in vitro conditions. The findings may help to explain the salt tolerance mechanisms and to produce salt-tolerant canola plants.

Acknowledgements: This study was supported by grants from the Payame Noor University of Iran.

\section{REFERENCES}

Antoline M. C., Sauchez-Dais M. 1992. Photosynthetic nutrient use deficiency, nodule activity and solute accumulation in drought stressed alfalfa plants. Photosynthetica 27: 595-604.

BANINASAB B., GHOBADI C. 2011. Influence of paclobutrazol and application methods on high temperature stress injury in cucumber seedling. J. Plant. Growth. Reg. 30: 213-219.

BARAKAT N. A. M. 2011. Oxidative stress markers and antioxidant potential of wheat treated with phytohormones under salinity stress. J. Stress. Physiol. Biochem. 7: 250-267.

Blumwald E., Grover A. 2006. Salt tolerance. In: Plant biotechnology: current and future uses of genetically modified crops (HALFORD N. G., Eds), pp. 206-224, John Wiley and Sons Ltd, UK.

Borsani O., Valpuesta V., Botella M. A. 2001. Evidence for a role of salicylic acid in the oxidative damage generated by $\mathrm{NaCl}$ and osmotic stress in Arabidopsis seedlings. Plant Physiol. 126: $1024-1030$.

BRADFORD M. 1976. A rapid and sensitive method for the quantitation of microgram quantities of protein utilizing the principle of protein-dye binding. Annals of Biochem. 72: 248-254.

Burkhanova E. A., Fedina A. B., Kulaeva O. N. 1999. Effect of salicylic acid and (2/ -5 )-oligoadenylates on protein synthesis in tobacco leaves under heat shock conditions: a comparative study. Russ. J. Plant. Physiol. 46: 16-22.

Bybordi A. 2010. Effects of salinity and $\mathrm{N}$ on the growth, photosynthesis and $\mathrm{N}$ status of canola (Brassica napus L.). Not. Sci. Biol. 2: 92-97.

Carillo P., Gibon Y., Prometheuswiki Contributors. 2011. Extraction and determination of proline [Internet]. PrometheusWiki; 2011 May 31. http://www.publish.csiro.au/prometheuswiki/tikipagehistory.php?page=Extraction and determination of proline\&preview $=14$. 
Carillo P., Mastrolonardo G., Nacca F., Parisi D., Verlotta A., Fuggi A. 2008. Nitrogen metabolism in durum wheat under salinity: accumulation of proline and glycine betaine. Funct. Plant. Biol. 35: 412-426.

Christoffersen R. E., Laties G. G. 1982. Ethylene regulation of gene expression in carrots. Bontany 79: 4060-4063.

Delavari P. M., Baghizadeh A., Enteshari S. H., Kalantari K. H. M., Yazdanpanah A., Mousavi E. A. 2010. The effects of salicylic acid on some of biochemical and morphological characteristic of Ocimum basilicum under salinity stress. Aust. J. Basic. and Appl. Sci. 4: 4832-4845.

Demmig-Adams B. 1990. Carotenoids and photoprotection in plants: A role for the xanthophyll zeaxanthin. Biochim. Biophys. Acta. 1020: 1-24.

Eckhardt U., Grimm B., Hortensteiner S. 2004. Recent advances in chlorophyll biosynthesis and breakdown in higher plants. Plant. Mol. Biol. 56: 1-14.

El-Khallal S. M., Hathout T. A., El Raheim A., Ahsour A., Kerrit A. A. A. 2009. Brassinolide and salicylic acid induced antioxidant enzymes, hormonal balance and protein profile of maize plants grown under salt stress. Res. J. Agr. Biol. Sci. 5: 391-402.

El-Shinaby O. A., Nematalla M. M., Younis M. E., El-Bastawisy Z. M. 2002. Effect of kinetin on photosynthetic activity and carbohydrate content in waterlogged or seawater- treated Vigna sinensis and Zea mays plants. Plant Biosys. 136: 277-290.

El-Tayeb M. A. 2005. Response of barley Gains to the interactive effect of salinity and salicylic acid. Plant Growth Regul. 45: 215-225.

Epstein E., Norlyn J. D., Rush D. W., Kingsbury R. W., Kelley D. B., Cummingaham G. A., Wrona A. F. 1980. Saline culture of crops: a genetic approach. Sci. 210: 339-404.

Gepstein S., Grover A., Blumwald E. 2006. Producing biopharmaceuticals in the desert: building an abiotic stress tolerance in plants for salt, heat and drought. In: Modern biopharmaceuticals (Knablein J., Muller R. H., Eds), pp. 967-994, Wiley-VCH Verlag GmbH, Wein- Haum.

Ghorbani Javid M., Sorooshzadeh A., Moradi F., Modarres Sanavy S. A. M., Allahdadi I. 2011. The role of phytohormones in alleviating salt stress in crop plants. Aust. J. Crop. Sci. 5: $726-734$.

Girija C., Smith B. N., Swamy P. M. 2002. Interactive effects of sodium chloride and calcium chloride on the accumulation of proline and glycinebetaine in Peanut (Arachis hypogaea L.). Environ. Exp. Bot. 47: 1-10.

GLass A. D. M. 1975. Inhibition of phosphate uptake in barley roots by hydroxyl-benzoic acids. Phytochemistry 14: 2127-2130.

Gunstone D. F., Harwood J. L., Padley F. B. 1995. The lipid handbook. Chapman and Hall Press, London.

Hajduch M., Casteel J. E., Hurrelmeyer K. E., Song Z., Agrawal G. K., Thelen J. J. 2006. Proteomic analysis of seed filling in Brassica napus developmental characterization of metabolic isozymes using high-resolution two-dimensional gel electrophoresis. Plant Physiol. 141: $32-46$.

Hamdia M. A., Shaddad M. A. K. 2010. Salt tolerance of crop plants. J. Stress Physiol. Biochem. 6: 64-90.

Hamid M., Ur-Rehman K., Ashraf M. Y. 2010. Salicylic acid-induced growth and biochemical changes in salt-stressed wheat. Commun. Soil Sci. Plant. 41: 373-389.

Hare P. D., Cress W. A. 1997. Metabolic implications of stress-induced proline accumulation in plants. Plant Growth Regul. 21: 79-102.

Hashemi S., Asrar Z., Pourseyedi S. 2010. Effects of seed pretreatment by salicylic acid on growth and some physiological and biochemical parameters in Lepidium sativum. Iran J. Plant Biol. 2: 1-10. (in Persian).

Haslam E. 1998. Practical polyphenolics: from structure to molecular recognition and physiological action. Cambridge University Press, Cambridge. 
Hummel I., Pantin F., Supice R., Piques M., Rolland G., Dauzat M., Christophe A., Pervent M., Bouteille M., Stitt M., Gibon Y., Muller B. 2010. Arabidopsis plants acclimate to water deficit at low cost through changes of carbon usage: an integrated perspective using growth, metabolite, enzyme and gene expression analysis. Plant Physiol. 154: 357-372.

Hussein M. M., Balbaa L. K., Gaballah M. S. 2007. Salicylic acid and salinity effects on growth of maize plants. Res. J. Agr. Biol. Sci. 3: 321-328.

Hyoda H., YANG S. H. 1971. Ethylene enhances synthesis of phenylalanine ammonialyase in pea seedlings. Plant Physiol. 47: 765-770.

Jamil M., Ashraf M., Rehman Su., Ahmad M., Rha E. S. 2012. Salinity induced changes in cell membrane stability, protein and RNA contents. Afr. J. Biotechnol. 11: 6476-6483.

Kang G., Li G., Zheng B., Han Q., Wang C., Zhu Y., Guo T. 2012. Proteomic analysis on salicylic acid-induced salt tolerance in common wheat seedling (Triticum aestivum L.). Biochim. Biophys. Acta. 1824: 1324-1333.

Kaydan D., Yagmur M., OKut N. 2007. Effects of salicylic acid on the growth and some physiological characters in salt stressed wheat (Triticum aestivum L.). Tarim Bilimleri Dergisi 13: $114-119$.

Khedr A. H. A., Abbas M. A., Wahid A. A. A., Quick W. P., Abogadallah G. M. 2003. Proline induces the expression of salt-stress-responsive proteins and may improve the adaptation of Pancratium maritimum L. to salt-stress. J. Exp. Bot. 54: 2553-2562.

Klessig D. F., Malamy J. 1994. The salicylic acid signal in plants. Plant. Mol. Biol. 26: 1439 - 1458.

KLIEBENSTEIN D. J. 2004. Secondary metabolites and plant/environment interactions: a view through Arabidopsis thaliana tinged glasses. Plant Cell Environ. 27: 675-684.

Kong-Ngern K., Daduang S., Wongkham C. H., Bunnag S., Kosittrakuna M., Theerakulpisuta P. 2005. Protein profiles in response to salt stress in leaf sheaths of rice seedlings. Science Asia 31: 403-408.

Krizek D. T., Brita S. J., Miewcki R. M. 1998. Inhibitory effects of ambient level of solar UV-A and UV-B on growth of cv. New Red Fire lettuce. Plant Physiol. 103: 1-7.

Larque-SaAveda A. 1979. Stomatal closure in response to salicylic acid treatment. Z. Pflanzenphysiol. 93: 371-375.

Leung J., Bouvier-Durand M., Morris P. C., Guerrier D., Chedfor F., Giraudat J. 1994. Arabidopsis ABA-response gene ABI1: features of a calcium-modulated protein phosphatase. Sci. 264: $1448-1452$.

Levent Tuna A., Kaya C., Dikilitas M., Yokas I., Burun B., Altunlu H 2007. Comparative effects of various salicylic acid derivatives on key growth parameters and some enzyme activities in salinity stressed maize (Zea mays L.) plants. Pak. J. Bot. 39: 787-798.

Lichtenthaler H. K. 1987. Chlorophylls and carotenoids: Pigments of photosynthetic biomembranes. Method Enzymol. 148: 350-382.

LiU J., ZhU J. K. 1997. An Arabidopsis mutant that requires increased calcium for potassium nutrition and salt tolerance. Proc. Nath. Acad. Sci. U. S. A. 94: 14960-14964.

Lopes F., Vansuyt G., Fourcroy P., Casse-Delbart F. 1994. Accumulation of 22-KDa protein and its mRNA in the leaves of Raphanus sativus in response to salt stress or water deficit. Physiol. Plant. 91: 605-614.

Maggio A., Miyazaki S., Veronese P., Fujtia T., Ibeas J. I., Damsz B., Narasihan M. L., Hasegawa P. M., Joly R. J., Bressan R. A. 2002. Does proline accumulation play an active role in stressinduced growth reduction? Plant J. 31: 699-712.

Mattioli R., Costantino P., Trovato M. 2009. Proline accumulation in plants: not only stress. Plant. Signal. Behav. 4: 1016-1018.

Mckersie B. D., Senaratna T., Walker M. A., Kendall E. J., Hetherington P. R. 1988. Deterioration of membranes during aging in plants: Evidence for free radical mediation. In: Senescence and aging in plants (Nooden L.D., Leopold A. C., Eds), pp. 442-464, .Academic Press, London, UK. 
MikoŁajczyk M., Awotunde O. S., Muszyska G., Klessig D. F., Dobrowolska A. G. 2000. Osmotic stress induces rapid activation of a salicylic acid-induced protein kinase and a homolog of protein kinase ASK1 in tobacco cells. The Plant Cell 12: 165-178.

Misra N., SaXena P. 2009. Effect of salicylic acid on proline metabolism in lentil grown under salinity stress. Plant Sci. 177: 181-189.

Mittova V., Theodoulou F. L., Kiddle G., Volokita M., Tal M., Foyer C. H., Guy M. 2004. Comparison of mitochondrial ascorbate peroxidase in the cultivated tomato (Lycopersicom esculentum) and its wild salt-tolerant relative (L. penelli) - a role for matrix isoforms in protection against oxidative damage. Plant Cell Environ. 27: 237-250.

Mohrekar S. T., Lokhande (Mohrekar) S. D., Hara T., Tanaka R., Tanaka A., Chavan P. D. 2003. Effect of salicylic acid on chlorophyll and carotenoid contents of wheat and moong seedlings. Photosynthetica 41: 315-317.

Murashige T., Skoog F. 1962. A revised medium for rapid growth and bioassays with tobacco tissue cultures. Physiol. Plantarum 15: 473-497.

Nasr N., Khayami M., Heidari R., Jamei R. 2006. Genetic diversity among selected varieties of Brassica napus (Cruciferae) based on the biochemical composition of seeds. J. Sci. (University of Tehran) 32: 37-40.

Nazar R., Igbal N., Syeed S., Khan N. A. 2011. Salicylic acid alleviates decreases in photosynthesis under salt stress by enhancing nitrogen and sulfur assimilation and antioxidant metabolism differentially in two mungbean cultivars. J. Plant Physiol. 168: 807-815.

NoRTON G., HARRIS J. F. 1975. Compositional changes in developing rape seed (Brassica napus L.). Planta 123: 163-174.

Olson B. J. S. C., Markwell J. 2007. Current protocols in protein science. Detection and Assay Method. 48: 3.4.1 - 3.4.29.

Pancheva T. V., Popova L. P., Uzunova A. N. 1996. Effects of salicylic acid on growth and photosynthesis in barley plants. J. Plant Physiol. 149: 57-63.

Panda S., Biswal U. C. 1989. Aging induced changes in thylakoid membrane organization and photoinhibition of pigments. Photosynthetica 23: 507-516.

Parida A. K., Mittra B., Das T. K., Mohantly D. A. 2005. High salinity reduces the content of highly abundant 23-KDa protein of the mangrove Bruguiera parviffora. Planta 221: 135-140.

Pavlikova D., Pavlik M., Staszkova L., Motyka V., Szakova J., Tlustos P., Balik J. 2008. Glutamate kinase as a potential biomarker of heavy metal stress in plants. Ecotox. Environ. Safe. 70: $223-230$.

PrZYMUSIŃSKi R., RuciŃKA R., GwoźDźE. A. 2004. Increased accumulation of pathogenesis-related proteins in response of lupine roots to various abiotic stresses. Environ. Exp. Bot. 52: 53-61.

Raskin I. 1992. Role of salicylic acid in plants. Annu. Rev. Plant. Physiol. Plant Mol. Biol. 43: 439-463.

Rostami F., Ehsanpour A. A. 2009. Application of silver thiosulfate (STS) on silver accumulation and protein pattern of potato (Solanum tuberosum L.) under in vitro culture. Malays Appl. Biol. 32: 49-54.

Sadia M., Salman A. M., Rabbani M. A., Pearce S. R. 2009. Electrophoretic characterization and the relationship between some Brassica species. Electron. J. Biol. 5: 1-4.

Sahi C., Singh A., Kumar K., Blumwald E., Grover A. 2006. Salt stress response in rice: genetics, molecular biology, and comparative genomics. Funct. Integr. Genomics 6: 263-284.

Sakaki T., Kondo N., Sugahara K. 1983. Breakdown of photosynthetic pigments and lipid in spinach leaves with ozone fumigation: role of active oxygen. Physiol. Plant. 59: 28-34.

Sakhanokho H. F., Kelley R.Y. 2009. Influence of salicylic acid on in vitro propagation and salt tolerance in Hibiscus acetosella and Hibiscus moscheutos (cv 'Luna Red'). Afr. J. Biotechnol. 8: 1474-1481. 
Salehi Z., McCarthy J. E. G. 2002. Structure and function of cap-associated proteins in yeast. PhD thesis, University of Manchester, Institute of Sciences and Technology (UMIST), Manchester, England.

Schaller G., Kieber J. 2002. Ethylene. The Arabidopsis Book 1: 1-17.

Senaratna T., Touchell D., Bunn E., Dixon K. 2000. Acetyl salicylic acid (Aspirin) and salicylic acid induce multiple stress tolerance in bean and tomato plants. Plant. Growth Reg. 30: $157-161$.

Shahba Z., Baghizadeh A., Vakili S. M., Yazdanpanah A., Yosefi M. 2010. The salicylic acid effect on the tomato (Lycopersicum esculentum Mill.) sugar, protein and proline contents under salinity stress $(\mathrm{NaCl})$. J. Biophys. Struct. Biol. 2: 35-41.

Shirani Bidabadi S., Mahmood M., Baninasab B., Ghobadi C. 2012. Influence of salicylic acid on morphological and physiological responses of banana (Musa acuminata $\mathrm{cv}$.'Berangan', AAA) shoot tips to in vitro water stress induced by polyethylene glycol. Plant. Omics. J. 5: 33-39.

Siefemann-Harms D. 1987. The light-harvesting and protective functions of carotenoids in photosynthetic membranes. Physiol. Plant. 69: 561-568.

Srichandan S. C., Choudhury N. K., Biswal U. C. 1989. Carotenoid degradation during in vitro aging of wheat chloroplasts. Photosynthetica 23: 687-690.

ŠTefl M., VASAKova L. 1984. Regulation of proline-inhibitable glutamate kinase (E.C. 2.7.2.11, ATP-gamma- L-glutamate phosphotransferase) of winter-wheat leaves by mono-valent cations and L-proline. Collect. Czech Chem. Commun. 49: 2698-2708.

Szabodos L., Savour A. 2010. Proline: a multifunctional amino acid. Trends Plant Sci. 15: 89-97.

Tari I., Csiszar J., Szalai G., Horvath F., Pecsvaradi A., Kiss G, Szepesi A., Szabo M., Erdei L. 2002. Acclimation of tomato plants to salinity stress after a salicylic acid pre-treatment. Acta Biol. Szegediensis. 46: 55-56.

Trovato M., Mattioli R., Costantino P. 2008. Multiple roles of proline in plant stress tolerance and development. Rendiconti Lincei 19: 325-346.

UNDOVENKO G. V. 1971. Effect of salinity of substrate on nitrogen metabolism of plants with different salt tolerance. Agro Khimiya 3: 23-31.

VASAKOVA L., ŠTEFL M. 1982. Glutamate kinases from winter-wheat leaves and some properties of the proline-inhibitable glutamate kinase. Collect. Czech Chem. Commun. 47: 349-359.

Vetbuggen N., Hermans C. 2008. Proline accumulation in plants: a review. Amino Acids 35: 753-759.

Ververidis F., Trantas E., Doglas C., Vollmer G., Kretzschmar G., Panopoulos N. 2007. Biotechnology of flavonoid and phenylpropanoid natural products Reconstruction of multienzyme pathway in plants and Microbes. Biotechnol. J. 2: 1235-1249.

Vettakkorumkankay N. N., Falk D., Saxena P., Fletcher R. A. 1999. A crucial role for gibberellins in stress protection of plants. Plant Cell Physiol. 40: 542-548.

VIJAYAN K. 2009. Approaches for enhancing salt tolerance in mulberry (Morus L.) - a review. Plant Omics. J. 2: 41-59.

Wasti S., Mimouni H., Smiti S., Zid E., Ben Ahmed H. 2012. Enhanced salt tolerance of tomatoes by exogenous salicylic acid applied through rooting medium. Omics 16: 200-207.

Xiong L., Schumaker K. S., Zhu J. K. 2002. Cell signaling during cold, drought, and salt stress. The Plant Cell Supplement: 165-183.

Yamane K., Rahman M. S., Kawaski M., Tniguchi M., Miyake H. 2004. Pretreatment with antioxidants decreases the effects of salt stress on chloroplast ultra-structure in rice leaf. Plant Production Sci. 7: 292-300.

Young A. J. 1991. The photoprotective role of carotenoids in higher plants. Physiol. Plant. 83: 702-708.

Zhang S., Klessig D. F. 1997. Salicylic acid activates a 48-kD MAP kinase in tobacco. Plant Cell 9: 809-824.

ZHU J. K. 2007. Plant salt stress. Encyclopedia Life Sci. 2: 1-3. 